\title{
Esboços de uma ética da educação em Sartre
}

\author{
Professor da Secretaria da Educação do Estado de São Paulo \\ Mestre em Educação pela UNICAMP
}

\section{Resumo}

O presente texto é uma investigação bibliográfica sobre a obra de Sartre, O Ser e o Nada. Delimita-se o foco em apresentar o projeto sartreano de pensar a condição bumana na sua existência radical, contingente e engajada no mundo. A atenção recai sobre o problema da liberdade que não se caracteriza de forma abstrata, mas que se concretiza na ação dentro de situação existencial e histórica. O objetivo é descrever a possibilidade de se pensar, a partir da compreensão sobre a condição humana, o esboço de uma ética para educação - entendida como a liberdade de criar-se a si mesmo, de maneira autêntica, enquanto ser no mundo engajado com a própria situação existencial e histórica.

Palavras-chave: Educação; Ética; Liberdade.

\begin{abstract}
This is a research based on literature on work by Sartre, Being and Nothingness. Our main objective is to present the sartrean project of thinking the human condition as radically contingent and engaged existences in the world. There is attention to the problem of freedom that is not characterized in the abstract, but which is actualized in action within the historical and existential situation. The objective is to describe the possibility of considering, from the perspective of the human condition, the sketch of an ethics from education - understood as the freedom of authentically creating oneself, as a being engaged in the world within his or her own historical and existential situation.
\end{abstract}

Key-words: Education; Ethics; Freedom. 


\section{Apresentação: Sartre - a existência em face à liberdade}

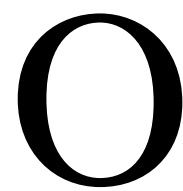

filósofo francês Jean-Paul Sartre (1905-1980), foi um dos principais expoentes do existencialismo. Seu pensamento transita por obras filosóficas, literárias e peças teatrais, cujo propósito visa primordialmente a compreensão da existência humana. A obra que tem marcado de maneira considerável a postura de Sartre no cenário filosófico, no âmbito do pensamento existencialista, tem sido O Ser e o Nada (1943). Como investigação voltada para a descrição do ser, tanto que ela subintitulase Ensaio de ontologia fenomenológica. Essa descrição se específica na relação entre o ser-Em-si ${ }^{1}$ (mundo) e o ser-Para-si ${ }^{2}$ (ser humano). Uma obra que se caracteriza como um tratado sobre a condenação do ser humano à liberdade de escolha; que desbrava seus próprios caminhos, rumo à construção do próprio ser, carregando o peso do mundo inteiro sobre seus ombros, pois se torna responsável por ele e por si mesmo na maneira de ser e agir. Uma liberdade engajada e compromissada com a própria situação existencial.

Tal postura filosófica de Sartre faz com que seu pensamento percorra os contornos ontológicos, antropológicos, éticos, políticos e estéticos, no enfrentamento dos grandes problemas de seu tempo. O que resulta na pergunta: será que Sartre, tem algo a dizer, frente aos desafios contemporâneos? Seu pensamento tem intensidade para o enfrentamento de problemas atuais? É pensando em uma resposta para essas questões, que o presente texto se ocupa, na tentativa de, a partir da filosofia sartreana, descrever a possibilidade de construir uma ética da Educação: um encontro

\footnotetext{
${ }^{1} \mathrm{O}$ Em-si corresponde ao mundo dos objetos, como ser que é, caracterizado como um ser opaco, denso, maciço, portador de uma identidade plena e marcada pela pura positividade. Isto o faz um ser fechado em si mesmo, denominado por três aspectos: o Ser é; o ser é em si; o Ser é o que é. (SARTRE, 2002, p.40)

${ }^{2}$ O Para-si (consciência) consiste em ser aquilo "que é o que não é e não é o que é" (SARTRE, 2002. p.116), constituindo a consciência como algo que não é. Esta definição faz como que ela se caracterize como pura negatividade, proporcionando uma abertura espontânea para o mundo, pela qual ela não é; e também não é uma identidade tal como se apresenta nos objetos.
} 
do pensamento sartreano com os problemas educacionais, na esfera ética. Mas Sartre não escreveu nenhum texto específico sobre ética, não há nenhum tratado sobre esse tema em suas obras, tampouco há sobre educação, não era um filósofo da educação. Como encontrar bases para essa pretensa construção? A possibilidade de se pensar uma educação a partir de seu pensamento, focando o tema da ética, nada mais é do que a liberdade de criação do leitor diante de sua obra, uma possibilidade que a própria filosofia sartreana traz à tona e sugere "Assim a minha liberdade, ao se manifestar, desvenda a liberdade do outro” (SARTRE, 1989, p.46). Neste aspecto figura a maestria de Sartre, ou seja, a inquietação que ele provoca, pela constatação (ontológica) do ser humano como condenado à liberdade e pela reivindicação ao exercício concreto dessa liberdade. Fato que faz de sua obra um apelo constante à liberdade, desde o escritor, que a escreve e a produz para que outros tenham a liberdade de mudar tudo. Trata-se de uma disposição para sempre transformar, criar, inventar o novo. Nesse caso, Esboços de uma ética da educação em Sartre é decorrência do exercício de uma ação livre de escrever a partir de uma experiência singular com a obra filosófica sartreana, na especificidade da ontologia da liberdade descrita em O Ser e o Nada, definida como autonomia da escolha, que atua frente às situações gerais que compõem a condição humana, com a prática e experiência da docência. Em suma, trata-se de partir da concepção de um Sartre livre, pensador privado, singular, que, ao criar, possibilita outras criações, que circunscreve esse trabalho. Algo que brota no meio de um pensamento autêntico, não para fazer dele modelo ou método, mas como ato provocativo de livres possibilidades para novas criações.

No rastro da grande paixão de Sartre, o de “compreender os homens” (JEANSON, 1987, p.v), enquanto seres livres, responsáveis, comprometidos e engajados com a sua situação existencial e histórica, que se apresenta este trabalho. A possibilidade de traçar uma investigação sobre educação, com o intuito de tornar possível a construção de uma ética, a partir da liberdade. Uma maneira de situar o pensamento sartreano dentro dos problemas educacionais, criando uma ética da educação em que se descreve a partir de 
uma ontologia antropológica, contornada também por aspectos políticos e estéticos. Uma ética na educação que estabelece ações concretas para a construção de um modo singular de ser e agir sem perder de vista o comprometimento e a responsabilidade com a humanidade toda. Ou seja, a construção de uma educação que lança o ser humano para uma ação concreta frente à vida cotidiana marcada pela situação existencial (singular) e pela história (coletiva), uma vez que, para Sartre, em cada época a condição humana aprende com os enigmas e desafios propostos pela liberdade, colocados por cada situação particular.

Desse modo, o texto propõe uma investigação sobre o projeto existencialista sartreano, que resulta na compreensão da condição humana na realidade em que se situa, em que em tudo e por tudo está envolvida a ação do ser humano; para dessa maneira constituir uma ética educacional pautada na liberdade no engajamento. Pensar em Sartre educador, não para ser discípulo e criar uma doutrina (escola), mas um educador livre que exorta a busca pessoal: a disposição livre para construir uma maneira de ser singular e um agir comprometido e responsável.

\section{O ser condenado à liberdade: a ética sartreana}

O foco central do pensamento sartreano recai exclusivamente sobre o ser humano e sua relação com o mundo: “a compreensão da existência como condição e da contingência como o seu horizonte-limite" (LEOPOLDO E SILVA, 2005, p.12). Ou seja, o projeto de pensar a realidade humana em Sartre passa precedentemente não pela compreensão da essência, que seria algo necessário, caracterizado como natureza humana, mas sim pela existência, na sua radical contingência, enfatizando a condição humana. Trata-se de um olhar sobre o ser humano numa atitude de interrogação contínua sobre sua própria condição, como projeto perpétuo de construção do ser. Assim, o existencialismo sartreano está voltado para tudo que compreende a realidade humana. 
Para Sartre (1970, p.247), todo estudo sobre a condição humana deve ter por princípio a subjetividade. No entanto, contrário ao pensamento moderno, ele elabora uma subjetividade caracterizada por uma consciência aberta, vazia de conteúdo, um nada de ser totalmente destituída de uma interioridade que a defina como alguma coisa. Fazendo com que a primeira atitude filosófica seja a de destituir da consciência todo e qualquer conteúdo, priorizando a relação dela (nada) com o mundo. (SARTRE, 2002, p.22)

O fato de que (o) nada habite o âmago de seu ser faz com que a realidade humana constate a liberdade como condição de sua existência. Caso contrário, se o ser fosse o que é (Em-si), nunca poderia ser livre. Isso porque estaria fadado, de uma vez para sempre, a um sentido - um ser dado a priori - na sua interioridade, antes mesmo da sua existência, resultando em um determinismo que seria a causa de seu ser e os motivos de seus atos. $\mathrm{Na}$ articulação do pensamento sartreano, esse procedimento não acontece, pois o ser humano, lançado no mundo, na exterioridade, tem que se fazer ser, ou melhor, escolher seu ser, caracterizando a liberdade como existência, e não como essência. Isto faz com que a liberdade se constitua como modo de ser da consciência (Para-si). Dessa maneira, a liberdade aparece não como propriedade que pertença à essência do ser humano, mas como próprio ser do homem (que não tem essência). Para Sartre, a liberdade precede a essência do ser humano e a torna possível. Na liberdade a essência aparece em suspenso - significando dizer que liberdade e realidade humana são sinônimas (SARTRE, 2002, p.68).

A liberdade não se constitui como a essência do ser humano nem ela própria tem uma essência, mas ela torna-se a base para que haja essência, a possibilidade de criar-se continuamente. Em outras palavras, a liberdade, não sendo a essência do ser humano, se constitui como a própria existência (SARTRE, 2002, p.695); e visto que a existência precede a essência, a liberdade precede e torna possível a criação de essências, uma criação possível somente pela liberdade que surge de forma concreta e se manifesta pela escolha. Daí que o conceito específico de liberdade que percorre $\mathrm{O}$ Ser 
e o Nada corresponde à autonomia de escolha (SARTRE, 2002, p.68), não havendo diferença entre ambas.

A escolha, segundo Sartre, se caracteriza como absoluta, fazendo com que a realidade humana esteja condenada a ser livre para escolher. Tanto que o próprio fato de não escolher também se caracteriza como escolha: a de escolher não escolher (SARTRE, 2002, p.592). Note-se que a liberdade não significa obter o que quer, um resultado - que seria uma representação que se pode escolher, resultando num porvir determinado. A liberdade consiste em um determinar-se por si mesmo ao querer, um exercício da ação. Assim, a liberdade existe pela escolha que faz de seu fim, sem levar em conta que o resultado dessas ações livres possa estar previsto ou que seja alcançado, ou seja, uma projeção rumo a um fim possível no âmbito do desejado e não do realizado. Para o filósofo francês, ser livre resulta em uma possibilidade de realizar seus próprios projetos (fins). Entenda-se esse fim como um esboço de uma ordem do existente, uma série de disposições a serem tomadas por ele (existente) (SARTRE, 2002, p.595), decisões situadas em meio às suas relações atuais, pelas quais deve fazer escolhas, anunciando a si mesmo aquilo que o constitui - ser escolha.

Para o autor d'O Ser e o Nada, o projeto original do Para-si como serno-mundo consiste em ser escolha. Isso significa que o Para-si (nada) ancorado na liberdade está condenando a fazer escolhas que lhe criem um modo de ser no mundo. Esse fazer-se de si mesmo torna-se possível somente pela liberdade de escolha, que nunca se realiza de maneira deliberada. Isso se deve ao fato de que cada escolha se identifica com a consciência, fazendo com que a consciência (de) si e a escolha sejam uma única coisa (SARTRE, 2002, p.569). Nessa perspectiva, pela escolha o ser se faz; e escolhendo se faz consciente. Ou ainda: o ser humano tem consciência de cada escolha que faz, em meio a sua própria situação ${ }^{3}$

\footnotetext{
${ }^{3}$ Situação corresponde a um termo existencialista e o primeiro a utilizá-la foi Karl Jaspers, sob o signo de situações-limite que correspondem às circunstâncias extremas que colocam o indivíduo em face aos fatos inelutáveis da existência humana: o sofrimento, o acaso, a morte, etc (MACIEL, 1980, p.55).
} 
existencial. Desse modo, a situação torna-se o fio condutor por onde a liberdade traça a escolha, caracterizando-se como liberdade-situada.

Sartre destaca que a constituição do Para-si não deixa de levar em conta sua própria situação ${ }^{4}$. Ela aparece como totalidade organizada do ser-aí, que deve ser vivida, interpretada pelo ser-para-além (SARTRE, 2002, p.673). Contudo, as situações nunca podem determinar ou alterar o projeto de ser do Para-si. A liberdade de escolha sobressai a todas as situações; ela apenas aparece de maneira simplificada ou complicada conforme o projeto de escolha de cada um. Essa situação marca a constituição do Para-si como “ser-em-situação”, enquanto responsável por sua maneira de ser, e consequentemente do seu fazer, sem ser o fundamento de seu próprio ser. Assim, a liberdade consiste na capacidade de transcender a situação, para construção do próprio ser. Isto faz com que a consciência - enquanto nada de ser - e a liberdade caminhem juntas (WETZEL, 2001, p.72).

Somente em meio à situação existente o Para-si, através da ação, torna-se aquilo que escolhe ser na sua vida, ancorado apenas na liberdade como base para trilhar seu caminho e constituir-se como ser. Para Sartre (1970, p.216), o homem nada mais é do que aquilo que ele faz de si mesmo. Aquilo que ele faz de si mesmo consiste no projetar-se pela ação rumo à possibilidade de ser. Disto resulta que a liberdade corresponde à condição primordial para a ação, pela qual o Para-si transcende o mundo rumo às próprias possibilidades, condição que faz com que ele se defina exclusivamente pela ação.

Para Sartre o ser humano está condenado pela liberdade a escolher e a inventar seu ser, num contínuo fazer-se; e a cada ato aparece o valor como um tributo da escolha. Assim, a origem do valor consiste no ato livre de escolher e inventar ${ }^{5}$. Ou ainda, a liberdade constitui a base da criação dos valores e nada justifica escolher este ou aquele valor. Não há uma natureza

\footnotetext{
4 "É total facticidade, a contingência absoluta do mundo, de meu nascimento, de meu lugar, de meu passado, de meus arredores, do "fato" de meu próximo - e é minha liberdade sem limites enquanto aquilo que faz haja para mim uma facticidade" (SARTRE, 2002, pp. 672673).

5 “A gênese do valor é o ato livre a escolher e a inventar” (BORNHEIM, 1971, p. 125).
} 
humana e não há também uma ordem de valores preestabelecidos. O Para-si (como ser pelo qual os valores existem) faz com que tanto ele quanto o valor sejam injustificáveis. Isto torna o valor consubstancial ao Para-si, como falta de ser que tende a ser. Isto também faz com que não haja consciência que não seja impregnada de valor. Em Sartre (2002, pp.691692), tanto faz dizer o valor possível existente como falta de ser quanto dizer que a liberdade ao projetar-se como possível circunscreve o valor. Assim, a consciência reflexiva permanece livre tanto para sugerir (criar) os valores, como também para negligenciá-los. Destaca-se que, no pensamento sartreano, a escolha livre antecede até mesmo a vontade: “Quando a vontade intervém, a decisão já está tomada, e a vontade não tem outro valor senão o de anunciadora” (SARTRE, 2002, p. 557).

O ato da escolha é parte integrante da sua maneira de ser, que tem como condição fundamental exclusivamente a liberdade. Esta, segundo Sartre, necessitaria de uma maior precisão, algo que para ele resultaria numa grande dificuldade: “descrever, comumente, é uma atividade de explicação visando as estruturas de uma essência singular. Mas a liberdade não tem essência” (SARTRE, 2002. p. 541). O que significa afirmar, como descrito anteriormente, que a liberdade, enquanto não tem uma essência, possibilita a criação de todas as essências (sentidos), fazendo com que o ser humano desvele as essências intramundanas ao transcender o mundo rumo às próprias possibilidades.

Desta forma, a concepção sartreana não define a condição humana em uma sentença: o homem é livre (o que ressoaria como algo acabado e fechado - a definição da essência humana como liberdade). Tal descrição resultaria em uma dicotomia entre o ser humano e a liberdade, fazendo com que a liberdade seja essencialmente um atributo da realidade humana. Para Sartre, a liberdade, corresponde à própria existência que precede a qualquer essência, expondo o ser humano às inúmeras possibilidades para criar-se. Assim, a liberdade se manifesta translúcida da mesma maneira que parece a consciência (nada), sem que algo a defina; caracterizada apenas como uma abertura do ser humano que transcende para aquilo que deseja ser. Para 
Sartre, todas as maneiras de ser manifestam igualmente a liberdade como um ato espontâneo de inventar-se, devido ao fato de que todas elas estão correlacionadas ao próprio nada, o que possibilita ser.

Assim, as características que definem o projeto de Sartre sobre a condição humana, cingida pelo nada de ser e pela liberdade de escolha, cuja consequência implica no comprometimento com a própria situação existencial quanto à constituição de sentidos e valores, fazem com que na relação com o mundo não deixe de haver uma dimensão ética. Aliás, “a ética configura a base intencional de tudo que ele escreveu” (LEOPOLDO E SILVA, 2004, p.16). Ou seja, todas as obras de Sartre contornam em algum aspecto a problemática ética.

Para o filósofo francês, cada decisão no presente está desprovida de um fundamento ou de uma eficácia justificável que sustente certa decisão a tomar, seja este o fundamento de um porvir determinado no futuro ou uma causa dada no passado. Há apenas a total liberdade das condutas a serem realizadas. A cada ação tomada pelo ser humano simultaneamente institui-se um valor (ou sentido) e nada pode impedi-lo de fazê-lo, a não ser sua própria liberdade, algo realizado de maneira injustificável, solitária e sem desculpas; cabendo a cada um exclusivamente decidir por si só a maneira de ser e agir.

No pensamento sartreano, o valor, componente intrínseco a dimensão ética, consiste na falta (SIMONT, 1998, p. 200) e sempre se revela pela liberdade ativa. Somente pela liberdade os valores são "fundamentados" e nada justifica a escolha desse ou daquele valor (SARTRE, 2002, p.83). Por este aspecto, a liberdade traz simultaneamente a angústia ao ser humano, por ela ser fundamento sem fundamento dos valores, que, por sua vez, são sempre colocados em questão, havendo a possibilidade de inverter suas escalas a partir da própria possibilidade do ser humano. Dessa maneira, ao apresentar a realidade humana como criadora dos valores, constitui, na liberdade de suas ações, uma ética em face à angústia - o que não acontece na moral cotidiana, que exclui a angústia, pois os valores já estão dados, 
basta conhecê-los e segui-los para ser considerado um indivíduo de boa índole moral. Para Sartre (2002, p.82), existe angústia na ética justamente porque há uma relação original com os valores, ou seja, há apenas a sua criação (livre). Isto torna o ser humano totalmente responsável tanto pelas suas ações livres como pela própria criação do seu ser.

No existencialismo sartreano, a responsabilidade consiste em nada mais do que a consciência (de) ser o autor incontestável dos acontecimentos de seus atos, pois, uma vez que o Para-si se faz independente da situação, ele deve assumir esse fazer como o único autor, assumindo também as consequências desses atos. Para Sartre (2002, p.678), a responsabilidade aparece como simples reivindicação lógica das consequências da liberdade em cada situação, “(...) o indivíduo, abandonado e carente da solidariedade de todos os outros, é solidário de todos os outros, escolhe ser homem por toda humanidade.” (LEOPOLDO E SILVA, 2004, p. 32). Uma ação universal e concreta que implicada na conduta singular, manifestando desse modo o teor ético da ação individual. Dessa maneira, pela liberdade o homem está abandonado no mundo (SARTRE, 2002, p.680). Isso não quer dizer que ele esteja desamparado e passivo no mundo. Pelo contrário, abandonado porque está sozinho e sem ajuda, pois não encontra nele próprio valores a priori e nem fora dele algo a que se apegue - não há desculpas. No entanto, ele traça seu caminho totalmente compromissado com o mundo pelo qual se responsabiliza. É responsável até por livrar-se da responsabilidade, diz Sartre (2002, p.680), o que torna o ser humano totalmente comprometido com a escolha que faz, estando consciente dela para mudá-la ou não. Assim, a responsabilidade torna-se parte intrínseca da realidade humana, uma condição própria da constituição da consciência como nada de ser, e da liberdade de escolha. Nessa escolha de ser o homem escolha por toda humanidade, pois estão implicados, além da liberdade, simultaneamente, a responsabilidade e o compromisso com os próprios atos, significando que o homem carrega nos ombros o peso do mundo inteiro (SARTRE, 2002, p.678). 
Nessa perspectiva, a ação humana, enquanto escolha por toda a humanidade, sempre será histórica porque sempre será possibilitada pela liberdade situada. Isto não significa que o fazer a si mesmo da condição humana seja algo exclusivo da consciência ou algo apenas da história, mas da relação entre consciência (livre) e história (mundo). Nessa relação entre história e consciência há a construção ética na existência. Isto se realiza pelo fato de que todas as ações são opções livres da consciência que acabam por criar valores a cada escolha efetivada, que, por sua vez, consiste numa ação histórica envolvida por compromisso e responsabilidade ética.

A responsabilidade e o compromisso com a escolha livre dos próprios atos implicam no engajamento, que, de modo geral, consiste na tomada de consciência do ser humano quando evidencia sua condição de ser-nomundo, enquanto ser-em-situação. Precisamente o engajamento compreende toda ação livre para superar o quietismo, a atitude contemplativa, a dimensão idealizadora e utópica para comprometer-se, assumir a postura de transformação real da situação existencial e histórica. Dito de outra de maneira, o ser humano, livre, encontra-se em uma determinada situação existencial e histórica, em que tem que se fazer a todo instante (dando um sentido a sua existência), através de suas escolhas, sendo totalmente comprometido e responsável por elas e por toda a humanidade. E isto significa engajar-se na perspectiva sartreana.

Ser engajado, na concepção sartreana, compreende a maneira de lutar contra o espírito de seriedade. Este corresponde a uma inversão da ação ética do ser humano, como aquele que deixa de criar os valores e o sentido da própria vida, para ser determinado pela objetividade, para a certeza de que os valores são dados a priori e desde sempre constituem o mundo. Para Sartre (2002, p. 763), o espírito de seriedade tem essa dupla característica: “(...) considerar os valores como dados transcendentes, independentes da subjetividade humana, e transferir o caráter de 'desejável' da estrutura ontológica das coisas para sua simples constituição material”. Neste sentido, segundo Sartre, vivem no espírito de seriedade o materialista e o revolucionário, pois afirmam que se conhecem e se definem a partir do 
mundo que os oprime e por isso lutam para mudar esse mundo. Assim, tanto os materialistas quanto os revolucionários, ao priorizarem o objeto (mundo) sobre o sujeito, estão se constituindo como sérios. Dessa maneira, o espírito de seriedade acontece quando o ser humano deixa se tomar por objeto, ser constituído por ele, ou seja, quando a história, as causas sociais e coletivas determinam o modo de ser e agir do ser humano.

O espírito de seriedade também está relacionado ao modo de ser do indivíduo em meio a outros, quando eles estão unidos sem um projeto comum. Sartre cita o exemplo de pessoas que esperam o ônibus na Praça Saint-Germain, frente à igreja; embora estejam unidas, naquele momento, na espera do ônibus, nada há em comum e entre eles: cada indivíduo tem uma maneira própria de ser, uma crença, pertence a uma classe social e, embora diferentes em si, estão juntos na solidão, unificados pelo exterior, pelos quais são simbolizados e simplificados, resultando-se na caracterização como série - uma unidade provida de fora pela materialidade. Isto faz com que o espírito de seriedade seja uma manifestação da conduta de má-fé. Enquanto a má-fé figura-se como a ameaça da consciência em constituir uma identidade fechada, algo interno, o espírito de seriedade compreende a realização objetiva de se determinar pela realidade do mundo, algo externo.

Outra característica que marca a conduta ética no pensamento sartreano diz respeito à busca do ser humano pela vida autêntica. Embora Sartre não tenha desenvolvido amplamente o conceito de autenticidade, por toda a sua obra há, direta ou indiretamente, uma noção clara e subjacente sobre esse tema (COX, 2002, p.171). Ou seja, a condição de existência na liberdade, na responsabilidade, no engajamento, na construção do ser e na maneira de agir no mundo, sem cair na má-fé ou no espírito de seriedade, compõe a dimensão da autenticidade na constituição do ser humano. Assim, autenticidade consiste na existência da condição humana livre de uma

\footnotetext{
${ }^{6}$ A má-fé consiste ser o que é da mesma forma que a coisa é (Em-si), assumir uma identidade e ao mesmo tempo quer ter a consciência plena dela. Como também deliberar o poder de decisão da própria escolha a um outro. Sobre a Má-fé ver. SARTRE, 2002, pp. 92.118.
} 
substancialidade, seja ela a perspectiva do ser é ou do nada como algo que é, mas um contínuo projetar desse nada rumo ao vir a ser inacabado e incompleto que nunca se fechará, enquanto existente, em uma identidade. Esse agir na liberdade de escolha, pressupondo o fazer, concretiza-se em atos, em uma realização sem desculpas e sem remorsos, assumindo totalmente as consequências desses atos; estando comprometido e engajado com a própria situação existencial e histórica, decidindo se deve transformála ou não.

Nessa perspectiva, ainda que Sartre não tenha escrito um tratado específico sobre ética, seu pensamento pode ser descrito dentro de uma abordagem ética, pois a ética, como uma reflexão filosófica sobre a maneira de ser e agir, pode ser pautada na liberdade de escolha e na responsabilidade, conceitos-chave na filosofia sartreana, que são realizados diante de situações problemáticas. Isto significa que ser ético trata da construção livre e responsável da maneira de ser e agir diante dos dilemas das próprias situações existenciais, em uma busca incansável de criação de valores frente aos conflitos e conjuntos de regras estabelecidas. Dessa forma emerge uma ética sartreana, ancorada na liberdade de escolha, que cria os próprios valores; uma ética, segundo Sartre, que se assemelha à criação de uma obra de $\operatorname{arte}^{7}$. Na arte não existem valores estéticos a priori, eles aparecem depois, na coerência do quadro, na relação entre vontade de criação e resultado (SARTRE, 1970, pp.256-257). A semelhança entre elas se realiza especificamente porque ambas têm a criação e a invenção, não havendo nada de predeterminado antes da liberdade.

A possibilidade dessa ética sartreana sugere pensar na expressão livre de criar, de inventar uma maneira de ser e agir, que responda pelo ser humano na sua singularidade; é uma maneira de ser-no-mundo que não se perca em egoísmo e tampouco se dissipe em altruísmo, mas que assuma a responsabilidade e o compromisso frente à humanidade (SARTRE, 2002, p.763). Abandonado e sem desculpas, o ser humano trilha seu caminho, na

\footnotetext{
${ }^{7}$ Não há, em Sartre, uma ética estética; simplesmente trata-se de uma analogia (1970, pp. 256-257).
} 
possibilidade de criação de seu ser e de seu agir realizado de maneira livre frente ao mundo, caracterizando um modo próprio, singular, de existir. A descrição da responsabilidade, n’O Ser e o Nada, figura também como ponto relevante para se pensar uma ética sartreana. Denota-se que ser ético em Sartre consiste em ser livre e responsável; implicando engajamento frente à constituição do ser e da ação no mundo.

Resumindo, a perspectiva ética sartreana resulta na criação livre dos valores, pelos quais se deve responsabilizar. Para Sartre (1970, p. 266): “Além de que dizer que inventamos os valores não significa senão isto: a vida não tem sentido a priori”. A princípio a vida não é nada, cabe a cada um dar-lhe um sentido; e o valor consiste no sentido escolhido. Assim, a marca dessa ética está cingida pelo abandono (nada a priori), ou seja, é uma ética que não está ancorada em nenhum valor dado ou determinado, mas sim criada a partir da singularidade do ser, reapresentando a liberdade frente a cada situação existencial e histórica. Nada justifica a priori ou a posteriori um ato - o ser humano está abandonado, condenado à liberdade de escolher seus próprios atos atribuindo a eles simultaneamente a escolha dos valores. Também a escolha de um ato não fundamenta a escolha de outro; após um ato escolhido, este não pode ser fundamento para um outro, o ser está permeado novamente no nada; começa-se uma nova escolha (liberdade) de um novo ato (novo valor) e com responsabilidade. Isto faz com que o valor, na descrição de uma ética sartreana, não seja nem a priori nem a posteriori, mas extemporaneus (extemporâneo), uma expressão latina originária de extemperolais, que significa algo que não é mediado nem que foi preparado, mas algo improvisado, repentino, livre (SANTANA, 2010, p.65). Assim, o valor como extemporâneo sinaliza que não é fundamentado por um tempo anterior (a priori) e nem posterior (a posteriori), mas totalmente criado, improvisado na simultaneidade do ato de escolher: "Escolher isso ou aquilo é afirmar ao mesmo tempo o valor do que escolhemos” (SARTRE, 1970, p.219). Ou seja, o valor constitui cada ato do ser humano na tensão entre projeto rumo à construção do ser e atuação situação em que se encontra, 
sendo que nada justifica essa criação, nem o determinismo psíquico e nem a necessidade histórica, somente há liberdade.

\section{Liberdade e engajamento: esboços de uma ética sartreana na educação}

Como todo o empenho do pensamento de Sartre está voltado para o ser humano, como ser livre que atua no mundo, isto não significa que pensar a educação a partir de suas ideias seja elaborar uma educação para a liberdade. A educação, em sua etimologia latina (ex-ducere) significa o ato de levar, de conduzir de um lugar para outro, e afirmar a educação para liberdade corresponderia ao ato de conduzir o ser humano à liberdade, a ser livre, como se o ser humano não o fosse. Ora, para Sartre, o ser humano, enquanto existente, sempre estará condenado à liberdade, ou seja, esta educação, em seu próprio aspecto etimológico, perde o sentido de ser. (SANTANA, 2010, p.109) Assim, aproximar educação do pensamento sartreano significa apresentá-la como sinônimo de liberdade, ambas são um ato de conduzir o ser humano a algum lugar - a formação humana (educação) e a construção do ser (liberdade). Nesta perspectiva, a educação, trilhada pelos caminhos do pensamento sartreano, não tem uma definição, uma essência, mas consiste na própria existência, apresentando de maneira livre para escolher e se fazer através dos atos. Deste modo, a possibilidade de uma educação sartreana surge sem que haja uma definição a priori e sem propor um fim estabelecido (formação de um ideal), mas se manifesta por uma ação livre e sempre contínua. Ou seja, uma educação na liberdade para conduzir-se numa existência totalmente comprometida com a própria situação do ser-no-mundo; um processo educacional em que o ser humano projeta rumo aos próprios fins, às próprias possibilidades, para criar e ressignificar os sentidos que constituem a existência.

Nesta perspectiva, a educação na liberdade existe pela escolha que se faz dos seus fins, que não estabelece um ideal, uma meta a alcançar, mas uma série de disposições livres a serem escolhidas pelos existentes a partir 
do projeto de ser. Assim, os fins se apresentam de maneira inédita à existência, não importando se os resultados sejam alcançados ou previstos de antemão, pois o projeto de ser sempre será algo inacabado. Trata-se de uma educação que se volta para o âmbito da livre criação do novo a todo o momento, pois a consequência dessa ação, independentemente de ser boa ou ruim, não pode ser critério para novas ações. Trata-se sempre de um inventar (o novo) frente às inúmeras disposições a serem tomados pelos existentes (educador - educando) em meio à própria situação. Esta invenção se processa pelas escolhas e se realiza pelos atos, fazendo com que a escolha nunca seja feita de maneira deliberada, pois ela se identifica com a consciência, enquanto vazia de qualquer conteúdo. Assim, a educação deve proporcionar ao existente a possibilidade de fazer escolhas e consequentemente criar-se diante da situação existencial que se encontra. Esta perspectiva faz com que a educação seja sempre flexível e adaptável à liberdade da realidade humana em meio às condições e aos desafios existenciais em que ela está inserida.

Da mesma maneira que somente há liberdade em situação, também esta deve ser parte intrínseca da educação. Não há como pensar a educação sem a sua constituição na situação. Neste sentido, a educação deve ser construída, inventada, a partir da situação já constituída de significados, que precisam ser transpostos para criar novas possibilidades de significações.

Uma situação nunca pode condicionar ou modificar o projeto educacional, que consiste em criar singularidades que se lançam constantemente rumo às próprias possibilidades para construção de uma maneira particular de ser e agir. A educação constituída na liberdade tem que ultrapassar as situações, que aparecerão de forma simples ou complicada, dependendo da especificidade de cada projeto educacional. Ao ultrapassar a situação constituída, o projeto educacional possibilita ao ser humano, através das ações livres, tornar-se aquilo que ele escolher ser na sua vida, transformando a própria situação, ou criar um novo sentido para ela. Isto sugere que a educação sempre desenvolva práticas (ações) educacionais trabalhando em meio às diversas situações que configuram a 
existência, em envolvimento e comprometimento com questões que continuamente se apresentam para a condição humana, procurando examinar o problema que a cada momento se põe a ela, nas suas relações com o mundo, com as outras consciências e consigo mesma. Esta educação projeta o ser humano para a consciência de sua situação, fazendo também com que tenha consciência de sua realidade histórica, pois a educação, ao assumir a perspectiva da situação concreta da realidade humana, assume também o comprometimento com a dimensão histórica. Aliás, não há situação sem estar inserida na história. Porém, é importante destacar que, para Sartre, o ser humano não é resultado, nem produto e nem é determinado pela história, condição que o tornaria um objeto.

A constituição da educação como sinônimo de liberdade faz com que a educação possibilite ao ser humano a ação. Somente através da ação ele constrói a si mesmo de maneira singular e constitui o mundo. Pois, toda atuação consiste em mudar, transformar o mundo. Cabe a educação o papel de construção de uma maneira ser e de atuar da realidade humana, uma capacidade espontânea, livre de inventar a si mesmo e de criar um sentido para sua existência. Em outras palavras, ao transitar pela liberdade, na sua maneira de ser e agir, a educação deve promover sempre a liberdade, a libertação de todos. Esta perspectiva estabelece uma educação que crie processos educacionais possibilitando a busca por educar a si mesmo e educar a todos; um processo educativo libertário. Estas são as características de uma educação na dimensão da liberdade e do engajamento.

A criação de singularidades consiste em possibilitar, a cada um, o enfrentamento da diversidade que sua situação existencial e histórica impõe, para que pela liberdade invente seu próprio caminho, tornando-se responsável e comprometido por ele. Este feito corresponde à dimensão do engajamento, pensado por Sartre, e consiste em nada mais do que a consciência do ser humano como ser-em-situação, enquanto livre para escolher seus atos. Trata-se da compreensão de uma educação não contemplativa, idealizadora e utópica, mas comprometida, através da ação livre, com uma transformação tanto da condição humana como também 
social e histórica. Isto significa que o educador engajado, ao criar um projeto educacional, assume uma posição no mundo e se responsabiliza pelas consequências dessa criação. Tem a clareza de que cada ato, cada prática, desvela um mundo, cria maneiras de ser que podem ser mudadas a qualquer momento. Assim, o educador engajado consiste naquele que dá existência, sentido às coisas, que é capaz de negar ou transformar algo e, mais ainda, possibilita ao educando, livremente, fazer o mesmo. Ou seja, o educando engajado na sua situação existencial e histórica cria a si mesmo e dá sentido ao seu ser no mundo, sendo responsável e comprometido com toda humanidade.

Nesta perspectiva, aparece a dimensão da autenticidade, que consiste na existência livre, responsável, comprometida, engajada na construção do ser e na maneira de se intervir no mundo. Ela se constitui como um projeto de ser, algo que não se mantém fechado e acabado e sim aberto e incompleto, na construção do seu ser e na execução de seus atos. Isto faz o ser humano totalmente responsável pelas consequências de suas ações e engaja-o em sua situação existencial e histórica, pronto para transformá-la ou não.

A autenticidade consiste em se comprometer e se responsabilizar pelas ações, como sendo elas algo próprio da condição livre das escolhas que cada ser humano faz e não algo causado por determinismos externos ou pela condição de uma essência interior. Caso existisse tal essência e determinismo, ela livraria o ser humano de qualquer responsabilidade.

A educação livre e engajada deve possibilitar a existência autêntica, que corresponde a um projeto de ser que deve continuamente ser assumido e reassumido enquanto ser-em-situação, tomando como própria essa situação. Uma educação que possibilite a invenção de inúmeras maneiras de existir, de fazer-se ser, em um projetar sem fins definidos, em meio à própria situação existencial e histórica. Um fazer que ultrapasse os determinismos tanto externos como internos, para assim inventar a si mesmo pelas ações livres providas pelas possibilidades das próprias escolhas. 
Nesta perspectiva, pensar em uma ética para educação consiste na concretização do projeto de inventar a si mesmo através da liberdade de suas escolhas, a partir da exigência do meio em que se vive. Ou seja, educando e educadores são colocados em confronto com a sua própria situação, fazendo com que ela se apresente como o lugar para o exercício de uma educação de liberdade e não para ser determinada por ela. É uma educação de si, em que a condição humana está continuamente em construção, sem fins estabelecidos, tanto no modo de ser (antropológico), como no caráter (ético), como na ação social (política), e também na criação de um estilo de ser e se manifestar (estético).

O caráter ético na educação implica na ação pautada na liberdade radical, sem ficar preso a desculpas ou justificativas; uma liberdade consolidada somente frente à própria situação. Fato que marca liberdade não como algo abstrato, mas sim concreto na superação dos limites das situações adversas com que cada um se depara e contra as quais se luta a todo o momento. Uma educação em que todo agir seja livre, cuja implicação consiste na construção de si mesmo e da humanidade toda. Ao mesmo tempo, estabelece uma educação responsável, ou seja, em que existe responsabilidade por cada ação.

A ética na educação evidencia a importância dada à dimensão singular do ser humano e a possibilidade de escolher livremente, como também a inserção em uma época histórica, em uma atitude de comprometimento como ela. Isto faz com a educação seja definida como um modo de ser e de atuar em direção à condição humana, em sua maneira de educar, de criar práticas e políticas educacionais, em comprometimento com a própria realidade. Uma educação assim torna-se responsável por suas escolhas, por suas ações educacionais, e é consciente de que cada prática consiste numa imersão no mundo e em um comprometimento com ele.

Ser ético na educação é garantir a liberdade de inventar os próprios caminhos (práticas, estratégias, projetos educacionais), e assim inventar uma maneira de ser e agir, fazendo seus atores totalmente engajados e 
responsáveis pelos próprios atos. Não se trata de negar a boa formação cultural, acadêmica, o conhecimento dos livros, mas de afirmar que a educação na liberdade consiste em algo mais: no comprometimento com a própria situação existencial e histórica, com a singularidade e com a coletividade, com a vida constituída da capacidade de criar sentidos e valores. Significa sentir os pés sobre o solo do próprio mundo, o calor do outro, o cheiro da atmosfera, a dor e alegria do momento, desafiar os obstáculos pedagógicos impostos por práticas educacionais que não respondem à necessidade da realidade em que se vive, para que ela possa ser ressignificada, transformada, reinventada.

A condição ética na educação é compreendida dentro de uma existência concreta e dentro de uma particularidade histórica em que se está situado. E nela atuar na criação de sentidos e nas significações engajadas, em uma atitude crítica sobre a condição humana. Trata-se de um envolvimento com o mundo real, para a compreensão das significações que compõem esse real, fazendo com que o educando seja inserido não nas determinações e condicionamentos que o alienam, mas na liberdade para julgar essas significações, recompondo e reinventando o real.

Dessa maneira, a educação, apoiada nesse componente ético, não se caracterizará como uma mera abstração de ideias e de significações no mundo, muito menos uma alienação da realidade, em que todos os que fazem parte da educação deixam de se ver situados nela, mas é um campo onde podem surgir críticas, transformações e criações da realidade, novos sentidos para ela. Desse encontro de liberdades (educandos e educadores) surge uma compreensão sobre a condição humana e do mundo, e em cada um aparece a responsabilidade pelas consequências de sua criação. Isto mostra que a responsabilidade tem grande importância na concepção da educação. Também assumem um compromisso ético o educador e o educando, ao criarem, desvendam livremente um sentido para a compreensão da realidade e se tornam responsáveis por essa criação ou desvendamento. Trata-se de uma ética da liberdade de inventar-se e 
comprometer com a própria realidade, compor uma educação existencial e história.

\section{Referências}

BORNHEIM, G. Sartre: Metafísica e existencialismo. São Paulo: Perspectiva, 1971.

COHEN-SOLAL, A. Sartre. Trad. Paulo Neves. Porto Alegre : L\&PM, 2005.

CONTAT, M. et RYBALKA, M. Les Ecrits de Sartre. Cronologie bibliografique commenteé. Paris : Gallimard, 1970.

COX, G. Compreender Sartre. Trad. Hélio Magri Filho. Petrópolis: Editora Vozes, 2007.

JEANSON, F. Sartre. Trad. Elisa Salles, Rio de Janeiro: José Olympio Editora, 1987.

1965. Le problème moral et la pensée de Sartre. Paris: Éditions du Seuil,

LEOPOLDO e SILVA, F. Ética e literatura em Sartre: ensaios introdutórios. São Paulo: Editora Unesp, 2004 - (Coleção Biblioteca de Filosofia).

MACIEL, L. C. Sartre: vida e obra. Rio de Janeiro: Paz e Terra, 1980.

SANTANA, M.R 2004, (O) Nada como princípio metafísico na constituição da consciência. Disponível em http://www.urutagua.uem.br//006/06santana.htm. Acesso em: 10/05/2008.

. 2005, Consciência de Angústia: Articulações antropológicas e Jean-Paul

Sartre. Disponível em http://www.urutagua.uem.br//008/08santana.htm. Acesso em: 14/09/2008.

Educação às Moscas : cenário para uma educação de situaçôes em Jean-

Paul Sartre. Campinas, SP, 2010 (dissertação de mestrado)

SARTRE Jean-Paul. L'être et le néant: essai d'ontologie phénoménologie. Paris: Gallimard, 1998.

- O Ser e o Nada: Ensaio de ontologia fenomenológica, trad. P.

Perdigão, Petrópolis: Vozes, 2002.

. O Existencialismo é um Humanismo. Trad. Vergílio Ferreira,

Lisboa: Ed. Presença, 1970. - Que é a literatura? São Paulo: Editora Ática, 1989.

SIMONT, J. Jean-Paul Sartre: un demi-siècle de liberté. Paris: De Boeck \& Larcier, 1998.

WETZEL, M. La mawaise foi. Analyse. Paris: Hatier, 2001. 